\title{
Forecasting the Yield of Barley in the North-Western Part of the Oka Basin
}

\section{Rukhovich Olga $\mathrm{V}^{1 *}$, Dorofeeva $\mathrm{T}^{2}$ and Pukhovskiy Anatoliy $\mathrm{V}^{3}$}

${ }^{1}$ Chief Researcher, Pryanishnikov All-Russian Research Institute of Agrochemistry (VNIIA), Dr. Sci (Dr. Hab, Agrochemistry), Russia

${ }^{2}$ Researcher, VNIIA and master student of Russian State Agrarian University, Moscow Timiryazev Agricultural Academy

${ }^{3}$ Professor in department of General and engineering ecology, Russian State Agrarian University, Moscow Timiryazev Agricultural Academy, PhD (Chemistry), Dr. Sci (Dr. Hab, Agrochemistry), Russia

*Corresponding author: Rukhovich Olga V, Chief Researcher, Pryanishnikov All-Russian Research Institute of Agrochemistry (VNIIA), Dr. Sci (Dr. Hab, Agrochemistry), Russia, Email: o_ruhovich@mail.ru

\section{Abstract}

To forecast the possible harvest of spring barley for the future, the harvest characteristics obtained from the «Agrogeos» database were used. The database «Agrogeos» contains information about field experiments with barley Agrochemical service and Geonetwork, collected for the period 1966-1996 on the territory of the northwestern part of the Oka basin, where there are 5 regions: Moscow, Oryol, Kaluga, Smolensk, Tula. Information was collected on the yield of barley on the fertilizer-free option (control), on the fertilizer application (maximum yield) and on the variant with barley yield increase (the average value between the control and maximum yield). Since the experiments were initially not coordinated, we were forced to do it ourselves in the Google Earth program, knowing the name of the collective farm, the location of the central manor, you can roughly determine the location of the field. To create a linear model, you need to have data on the 3 main factors affecting ecosystem change: terrain, climate, and soils. Knowing their characteristics, it is possible to identify the main predictors that influence the yield of a possible crop and build a forecast map with a detailed description of yield yields for different methods of cultivation.

Keywords: Spring Barley; Yield Indicators; Data Bases; Spatial Variability; Relief; Climate; Geomorphometry; Multiple Regression 


\section{Open Access Journal of Agricultural Research}

\section{Introduction}

Quantitative analysis of the relationship between the characteristics of the earth's surface and soil characteristics was used by many authors. A study was made of the relationship between the characteristics of the earth's surface, for example, water content in soils and other hydrological characteristics, with the particle size distribution in the soils, with the thickness of the soil horizons, with the productivity of vegetation [1-21]. A number of studies have attempted to classify soils and landscapes on this basis $[5,8,12,15,19,22,23]$. But, for example, the evaluation of the thermal regime of the slopes with the help of morphometry has not been practically studied. In addition to the thermal regime, we also considered the influence of the microclimate on the yield of agricultural crops.

The entire historical experience of agriculture shows that in each, even a relatively small area, there are areas most favorable for the cultivation of a particular group of crops. Harvest in the agrolandscape is determined by the interaction and mutual influence of a common set of factors. Changes in hydrothermal, microclimatic and soil factors in agrolandscapes are difficult to predict. Depending on characteristics of the relief - height, steepness, slope exposition - soil fertility, thermal and water regime significantly changes, ie, basic abiotic and biotic parameters of the environment.

The relief changes with time slowly enough, i.e. is a constant, and its characteristics - morphometric values (MV) that vary in space, are easily accessible to measurement. However, it is impossible to describe the whole variety of processes and phenomena in the agrolandscape, defined by the relief, with only three of its characteristics. They do not reflect, for example, the important hydrological features of the relief, described by the drainage area, the main reasons for the differences in the thermal regime of slopes, which depend simultaneously on the steepness and exposition, dissection of relief etc.

An extended set of 18 basic morphometric values (MV) was first introduced along with a description of the meaning of each MV in the work [24].

The aim of this work is to study the influence of illumination and other morphometric values, as well as the climatic index (the average multi-year temperature in april - august) on the spatial distribution of various indicators of the winter wheat crop in the agro landscapes of the Oka River basin-ecosystems within the watershed, with the interaction and interdependence of its components.

\section{Methods}

For processing, the results of field experiments with fertilizers of Agrochemical service and Geonetwork of Russia with spring barley, conducted in different years in the territories of five administrative regions of the Russian Federation located within the northwestern part of the Oka River basin were selected (Figure 1).

For the calculations, the productivity of spring barley (a centner per hectare) was used, taking into account the landscape, climatic features of the territory or both. Indicators of the data on the variant without applying fertilizers, on the variant with obtaining the maximum yield and the average for variants with fertilizers. For each field experiment we had found its own geographical coordinates in Google Earth.

The NASA SRTM30 altitude matrices were transformed into a matrix in the Kavraisky projection with a resolution of 600 meters, which was used to calculate morphometric values, determine and analyze statistical relationships by correlation and multiple regression, qualitative and quantitative characteristics of the crop [25]. Matrices of the WorldClim database of mean multi-annual temperatures and precipitation from April to August (1966-1996) were created with the same resolution [26].

Multiple regression gives the imposition of maps (matrices) with values calculated from the statistical comparison of the measured characteristic of the agroecosystem with the selected morphometric values for sites with known planned coordinates. Three morphometric values, which correspond to the highest rank correlation coefficient of Spirman rS, are the main predictors, the change in space which first of all follows the given characteristic of the agroecosystem.

All calculations and the construction of cartographic schemes were completed with the computer program "Analytical GIS Eco".

The list of morphometric values is presented in Table 1.

\section{Conclusions}

N. M. Sibirtsev noted that the slope of the more heated sunlight, ceteris paribus, the closer the downfall of these 


\section{Open Access Journal of Agricultural Research}

rays to the perpendicular position, that is, the heating depends on the steepness and exposure at the same time $[27,28]$. This perpendicular is described by the illumination $F(a, b)$, depending on two angles: the declination of the Sun above horizon a and the azimuth of the Sun $b$. The values of $\mathrm{F}(\mathrm{a}, \mathrm{b})$ vary from $100 \%$ (perpendicular to the sun's rays) to $0 \%$ (shadow slopes). It is clear that ignoring the difference between heating steep and gentle slopes (as well as shadows) makes the results on the relationship of exposure $\mathrm{A} 0$ with the characteristics of the landscape difficult to reproduce. For these reasons, instead of exposure, this paper uses the illumination $\mathrm{F}(\mathrm{a}, \mathrm{b})$.

In statistical comparisons, the dependence of the correlation coefficient $\mathrm{rS}$ on the angle of inclination of the Sun is weak, compared with the dependence on the azimuth. In the Oka basin in the South azimuth of the Sun (near 180 degrees) exhibits the greatest values of $\mathrm{rS}$ for the quantitative indicators of the crop (total yield content of grain and straw), but in the South-West the azimuth of the Sun (near 225 degrees) exhibits the greatest values of rS for the qualitative characteristics of the crop (protein content in the grain and collecting the protein from 1 hectare). Since the heating of the soil at a depth of several tens of centimeters occurs with a delay due to the inertia of the heat penetration deep into, the greatest heating in the summer in the Northern hemisphere corresponds to the azimuth angles of the South-Western direction (North-Western in the southern hemisphere).

Thus, the yield of spring barley depends on the lighting of the slopes, and the indicators of crop quality-on the warming of the slopes. In many situations, the maximum value of $\mathrm{rS}$ in the selection of the program of GIS ECO efficient azimuth of the Sun is useful for the detection of such features of the spatial distribution of different characteristics of agroecosystems.
It is found that the formation of productivity is most affected by the relative position of the field on the slope, the steepness of the slope and its illumination. The potential of the crop is reduced on steeper slopes, illuminated from the South-West.

When entering into calculations of long-term average data of temperature and precipitation from April to August, the dependence of the quality and quantity of spring barley harvest on the microclimatic characteristics of the territory becomes obvious, since the relief acts as a distributor in the space of light, heat and moisture.

Thus, the regression equation for the control variant (without fertilizers), where the predictors are both the terrain and climate:

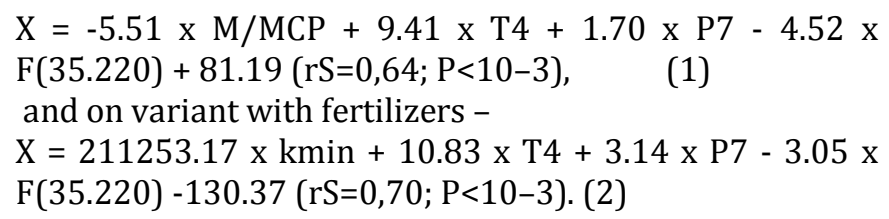

\section{Results}

The result of the resulting linear models in the form of maps of the potential yield of spring barley is reflected in Figures 2 and 3 with different cultivation technologies. Yield is indicated in hundredweights per hectare.

Practically for all studied quantitative characteristics of the spring barley harvest in the agroecosystems of the Oka basin, the illumination of the slopes from the southwest and the weather conditions are among the leading predictors, which reflects the importance of the spatial variability of the hydrothermal regime of the terrain for agroecosystems.

\begin{tabular}{|c|c|c|c|}
\hline № & Name of MV & Symbol & What describes \\
\hline \multicolumn{4}{|c|}{ MVs describe surface runoff } \\
\hline 0 & Exposion * of slopes & $A_{0}$ & Flow direction \\
\hline 1 & Steepness of slopes & $G A$ & Flow rate \\
\hline 2 & Horizontal curvature & $k h$ & \multirow{3}{*}{ The 1st accumulation mechanism } \\
\hline 3 & Drainage area & $M C A$ & \\
\hline $4^{* *}$ & Dispersive area & $M D A$ & \\
\hline 5 & Vertical curvature & $k v$ & The 2nd accumulation mechanism \\
\hline $6^{* *}$ & Difference curvature & $E$ & $\begin{array}{c}\text { Compares the 1st and the 2nd accumulation } \\
\text { mechanisms }\end{array}$ \\
\hline $7^{* *}$ & Full accumulative curvature & $K A$ & $\begin{array}{l}\text { Identifies areas of relative accumulation and } \\
\text { demolition }\end{array}$ \\
\hline
\end{tabular}




\section{Open Access Journal of Agricultural Research}

\begin{tabular}{|c|c|c|c|}
\hline \multicolumn{4}{|c|}{ MVs describe the dissection of the relief } \\
\hline $8^{* *}$ & Full ring curvature & $K R$ & Tortuosity of flows \\
\hline $9 * *$ & Horizontal excess curvature & khe & \multirow{2}{*}{$\begin{array}{l}\text { These two MVs split the tortuosity of the flows } \\
\text { into two components }\end{array}$} \\
\hline $10^{* *}$ & Vertical excess curvature & Kve & \\
\hline $11^{* *}$ & Rotor & rot & Direction of rotation of streamlines \\
\hline \multicolumn{4}{|c|}{ MVs describe memory in landscapes } \\
\hline $12^{* *}$ & Nonsphericity & $M$ & $\begin{array}{l}\text { Difference in the shape of the relief at the point } \\
\text { from the spherical }\end{array}$ \\
\hline $13^{* *}$ & Average curvature & $H$ & $\begin{array}{l}\text { "Equilibrium" (minimal) surface, having a } \\
\text { minimum area at the given boundary } * * *\end{array}$ \\
\hline $14^{* *}$ & Maximum curvature & kmax & Crest forms of relief \\
\hline $15^{* *}$ & Minimal curvature & kmin & Keel forms of relief \\
\hline $16^{* *}$ & Full Gaussian curvature & $K$ & Does not change when the surface is bent \\
\hline \multicolumn{4}{|c|}{ MV describes the thermal regime of the slopes } \\
\hline $17^{* *}$ & Slope illumination & $F$ & Intensity of direct solar radiation \\
\hline \multicolumn{4}{|c|}{ MV describes the altitudinal zoning } \\
\hline 18 & Height of the earth's surface & $Z$ & $\begin{array}{c}\text { Change in temperature and pressure of the } \\
\text { atmosphere }\end{array}$ \\
\hline
\end{tabular}

* The exposition was not used in the work for statistical comparisons.

** MVs, which were not used for analysis in the works of other authors.

*** The average curvature also describes both mechanisms of accumulation.

Table 1: Extended system of basic morphometric values.

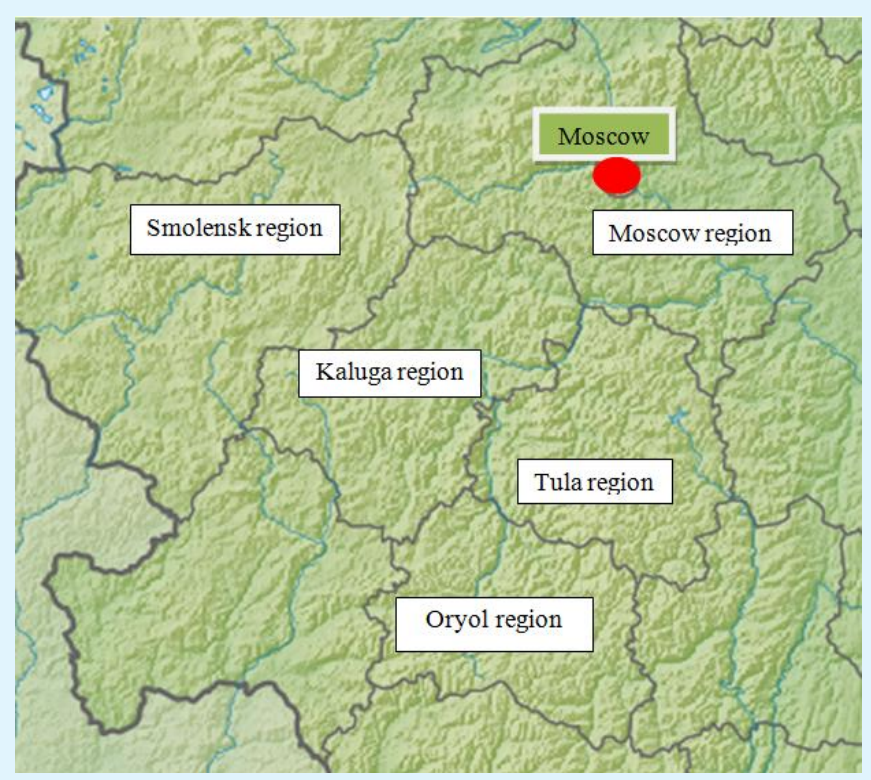

Figure 1: Administrative areas located in the north-western part of the Oka basin. 


\section{Open Access Journal of Agricultural Research}

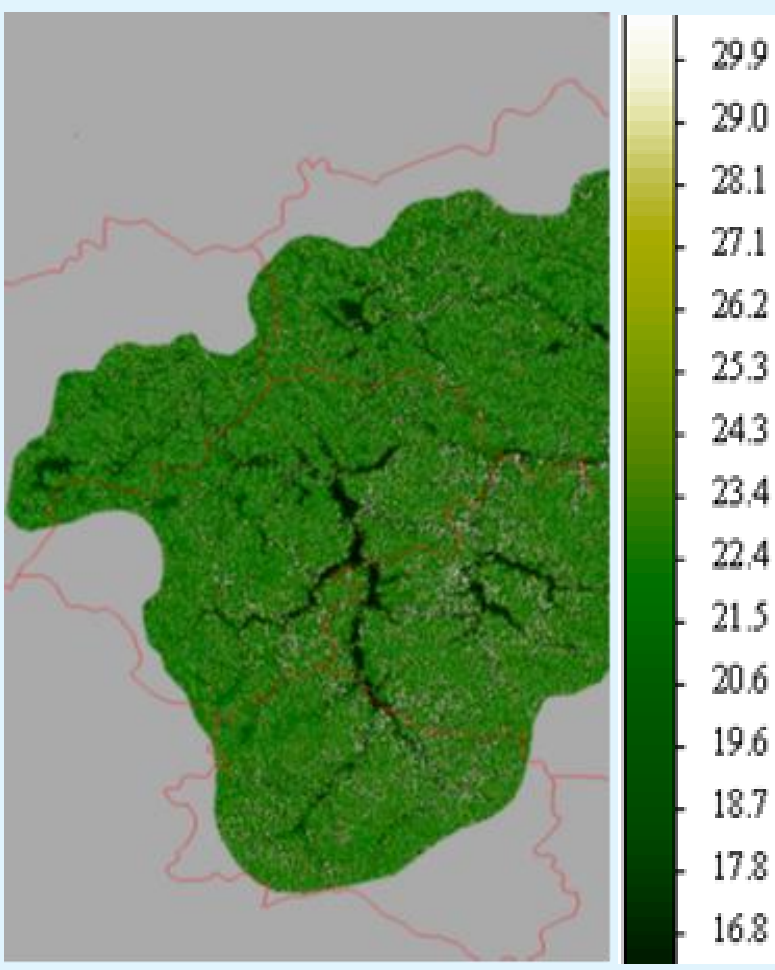

Figure 2: Potential yield with extensive technology of cultivation (without fertilizer application).

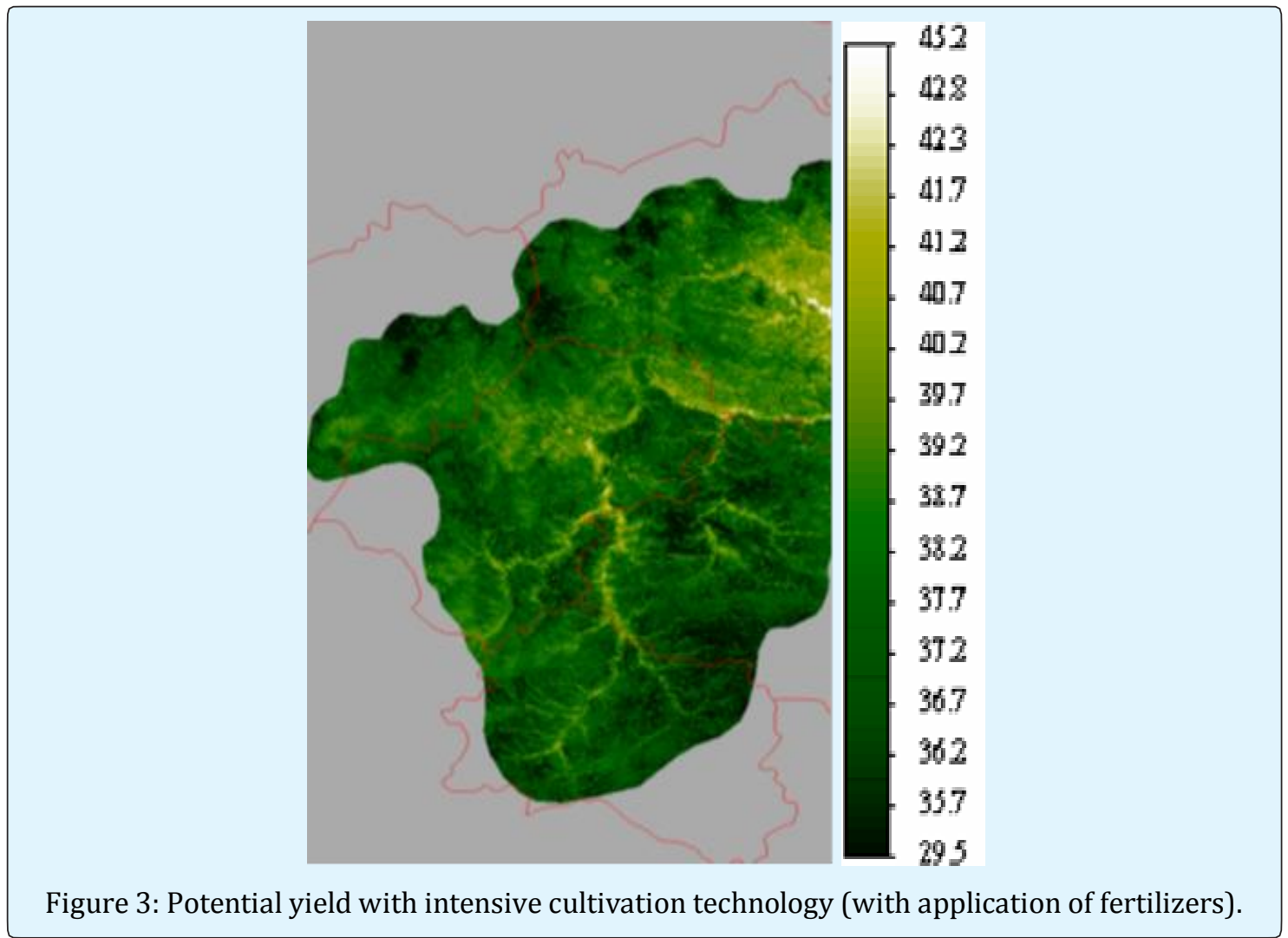




\section{Open Access Journal of Agricultural Research}

\section{References}

1. Beven KJ, Kirkby MJ (1979) A physically based, variable contributing area model of basin hydrology. Hydrological Sciences Bulletin 24(1): 43-69.

2. Bell JC, Cunningham RL, Havens MW (1992) Calibration and validation of a soil-landscape model for predicting soil drainage class. Soil Science Society of America Journal 56(6): 1860-1866.

3. Bell JC, Cunningham RL, Havens MW (1994) Soil drainage class probability mapping using a soillandscape model. Soil Science Society of America Journal 58(2): 464-470.

4. Sinai G, Zaslavsky D, Golany P (1981) The effect of soil surface curvature on moisture and yield-Beer Sheba observations. Soil Science 132(5): 367-375.

5. Troeh FR (1964) Landform parameters correlated to soil drainage. Soil Science Society of America Proceedings 28(6): 808-812.

6. Kuryakova GA, Florinsky IV, Shary PA (1992) On the correlation between soil moisture and certain topographic variables. In: Andronikov VL (Ed), The Modern Problems of Soil Geography and Mapping, Proceedings of National Conference, September 2426, 1991, Dokuchaev Soil Institute, Moscow pp: 70-71 (in Russian).

7. Moore ID, Grayson RB, Ladson AR (1991) Digital terrain modelling: a review of hydrological, geomorphological, and biological applications. Hydrological Processes 5: 3-30.

8. Moore ID, Gessler PE, Nielsen GA, Peterson GA (1993) Soil attribute prediction using terrain analysis. Soil Science Society of America Journal 57(2): 443-452.

9. Fiez TE, Pan WL, Miller BC (1995) Nitrogen use efficiency of winter wheat among landscape positions. Soil Science Society of America Journal 59: 16661671.

10. Huang C (1995) Empirical analysis of slope and runoff for sediment delivery from interrill areas. Soil Science Society of America Journal 59(4): 982-990.

11. Tomer MD, Anderson JL (1995) Variation of soil water storage across a sand plain hillslope. Soil Science Society of America Journal 59(4): 1091-1100.
12. McKenzie NJ, Ryan PJ (1999) Spatial prediction of soil properties using environmental correlation. Geoderma 89(1-2): 67-94.

13. Martz LW, de Jong E (1990) Natural radionuclides in the soils of a small agricultural basin in the Canadian Prairies and their association with topography, soil properties and erosion. Catena 17(1): 85-96.

14. Klich I, Wilding LP, Pfordresher AA (1990) Closeinterval spatial variability of Udertic Paleustalfs in east cantral Texas. Soil Science Society of America Journal 54: 489-494.

15. Odeh IOA, Chittleborough DJ, McBratney AB (1991) Elucidation of soil-landform interrelationships by canonical ordination analysis. Geoderma 49(1-2): 132.

16. King D, Bourennane H, Isampert M, Macaire JJ (1999) Relationship of the presence of a non-calcareous clayloam horizon to DEM attributes in a gently sloping area. Geoderma 89(1-2): 95-111.

17. Carter BJ, Ciolkosz EJ (1991) Slope gradient and aspect effects on soils developed from sandstone in Pennsylvania. Geoderma 49(3-4): 199-213.

18. Sinowski W, Auerswald K (1999) Using relief parameters in a discriminant analysis to stratify geological areas with different spatial variability of soil properties. Geoderma 89(1-2): 113-128.

19. Pennock DJ, de Jong E (1990) Regional and catenary variations in properties of Borolls of southern Saskatchewan Canada. Soil Science Society of America Journal 54: 1697-1701.

20. Simmons FW, Cassel DK, Daniels RB (1989) Landscape and soil property effects on corn grain yield response to tillage. Soil Science Society of America Journal 53(2): 534-539.

21. Timlin DJ, Pachepsky Ya, Snyder VA, Bryant RB (1998) Spatial and temporal variability of corn grain yield on a hillslope. Soil Science Society of America Journal 62(3): 764-773.

22. Odeh IOA, McBratney AB, Chittleborough DJ (1992a) Soil pattern recognition with fuzzy-c-means: application to classification and soil-landform interrelationships. Soil Science Society of America Journal 56(2): 505-516. 


\section{Open Access Journal of Agricultural Research}

23. Odeh IOA, McBratney AB, Chittleborough DJ (1992b) Fuzzy-c-means and kriging for mapping soils as a continuous system. Soil Science Society of America Journal 56(6): 1848-1854.

24. Shary PA, Sharaya LS, Mitusov AV (2002) Fundamental quantitative methods of land surface analysis. Geoderma 107(1-2): 1-32.

25. Rodriguez E, Morris CS, Belz JE, Chapin EC, Martin JM, et al. (2005) An assessment of the SRTM topographic products. Jet Propulsion Laboratory pp: 1-143.
26. Hijmans RJ, Cameron SE, Parra JL, Jones PJ, Jarvis A (2005) Very high resolution interpolated climate surfaces for global land areas. International Journal of Climatology 25(15): 1965-1978.

27. Sibirtsev NM (1900) Soil sciences: lectures. Soil science 1: 472 (in Russian).

28. Montgomery DC, Peck EA (1982) Introduction to Linear Regression Analysis. New York: John Wiley \& Sons pp: 504. 